DOI https://doi.org/10.30525/978-9934-26-065-0-3

Iwona Malewicz

"I am the Beginning of everything because Worlds emerge in my consciousness."

\title{
KAZIMIERZ MALEWICZ (1913)
}

As the granddaughter of Antoni, the brother of Kazimierz Malewicz, I have spent years promoting my ancestor's artistic legacy, presenting the artist in a context that is still little known to admirers of his work.

In this article, taking a narrow scope, I would like to address a few of these issues and share my own reflections and contemplations with the reader. I will also touch on the topic of family, and many other topics bothering me about the reformer of modern art of the 20th century - Kazimierz Malewicz. This is also the reason why this article will differ from academic papers of international art historians, or from professional literature that has been available on all continents for many years.

My intention is also to draw attention to the little known and understudied aspects of the great genius and art of the Father of Suprematism who paved the way for many well-known international artists (Wojciech Fangor, Ilya Kabakov, Donald Judd, Frank Stella) and architects (Zaha Hadid, Daniel Libeskind, Frank Gehry, Mario Botta) of the 20th and 21st centuries.

Kazimierz Malewicz is a genius of international art, architecture, poetry and vocabulary, who was born in Kyiv and came from a Polish Catholic noble family (his mother and father were Poles), which was awarded the title of nobility by King Sigismund III.

The issue of Polishness was repeatedly overlooked by Western historians, art researchers, and journalists; they spelled Malewicz's name incorrectly, in the 
Russian transliteration - Kasimir Malevich. As Professor Janusz Zagrodzki writes in the Catalog for the exhibition " 5 x Malewicz - Malewicz and Polish AvantGarde", which I initiated, organized, and curated:

"Art researchers did not bother to look for information that was not that hard to find: in the 19th and the first two decades of the 20th century, Poland did not exist as a state organism, and its inhabitants automatically were citizens of the three empires of Austria, Prussia, and Russia, greedy for their expansion.

In the modest catalog "Précurseurs de l'art abstrait en Pologne" compiled by Julian Przyboś and published on the occasion of the exhibition in Paris in 1957, the artist's name and surname were written in their Polish version, but this escaped everyone's attention. And yet, in the interwar period, everything was completely clear, even Malewicz's Russian friends knew about his "Western birth", and called him "Pan Malewicz" (Polish: Mr. Malewicz) to emphasize his special significance in the artistic environment. Władysław Strzemiński wrote in his article published in "Zwrotnica" magazine: "Malewicz is not the first Pole to dominate Russian art (Orłowski, Wróbel)". ${ }^{1}$

Professor Andrey Borys Nakov is another art historian who uses the Polish version of my ancestor's surname, thus emphasizing his Polish origin.

The Malewicz family lived in Polissia, Podilia, Volyn, Kyiv, and other regions. From the very beginning of our ancestors' family, they held high positions in the Uniate and Catholic Church, served as government and military officials (Kazimierz's grandfather was an artillery captain).

The Malewicz family kept Polish traditions and language in high regard. The artist's mother, Ludwika née Galinowska, wrote poems in Polish. She had literary and musical education, which she received thanks to her uncle, a composer. With great commitment, she shared her knowledge with her children, who were musically very gifted musically and played various instruments (e.g. Kazimierz played the piano, harmony and organs), and, just like their mother, wrote poems (Kazimierz, Wiktoria, Antoni, and Bolesław). I believe that bringing up children in the spirit of Polish culture had a great influence on the shaping of the artistic consciousness and personality of Kazimierz Malewicz.

Catalog from the Exhibition “5 x Malewicz," article by prof. Janusz Zagrodzki 
In Polish, Malewicz wrote “The Appeal to Polish Youth.” In March 1927, he also gave a lecture at the Polonia Palace Hotel in Warsaw, where his first foreign exhibition took place. The title was:

\section{ANALYSIS OF CONTEMPORARY ARTISTIC TRENDS}

The Black Square on White by "The Father of Suprematism", who is hailed by international art historians as a precursor, visionary, and reformer of contemporary art of the 20th century, has become an Icon for many generations of art creators, architects, and designers - and this continues in the 21st century.

This is how Malewicz describes his work:

"The Black Square on White" is "the naked, frameless Icon of its time".

"I did not display an "empty square." Instead, I displayed an impression of objectlessness".

"Square = impression, white background = "nothingness" beyond that impression".

"The joyful feeling of freedom offered by objectlessness took me into this "desert" where nothing is real but sensation... and it became the essence of my life».

The critics, followed by the audience, sobbed:

"Everything we loved is gone, we found ourselves in a desert... In front of us there is a black square on a white background!" ${ }^{2}$

The Black Square is one of the most dominant and recognizable works of art, visually showing an extreme breakthrough, revolution, as well as a manifesto and transformations in the shaping of a new period in world art of the 20th and 21th centuries.

The black color is a reflection of darkness, evil, catastrophe, sadness, mourning, and death. However, realizing the meaning of this word, like the father of Suprematism did, we can say that the plane of black, just like the plane of white, symbolize the Absolute, express the fullness of life and its total lack, opening before us the depths of infinite space. Black in this sense is eternity, wisdom, and sometimes mystery, graveness, and dignity.

\section{Fialkowski}

Kazimierz Malewicz The Non-Objective World, the Bauhaus library, translated by Stanislaw 
White is the color of light, a sign of subtlety, purity, impeccability, perfection; it is illumination, the unification of the beginning and the end. So white and black are the colors of great philosophical and sacred significance, but combining all meanings, we find in them the same concept of perfection, which was enshrined in Malewicz's Icon of the 20th century.

For Malevich, this paining was "not a form of the subconscious - it was a creative work of intuitive mind... The first step of pure creativity in art". There was everything, he told himself: the fullness of shape beyond reality, the fullness of color beyond all color, the supremacy of feeling - the ability to sense invisible energies, the embodied potential - this is suprematism $(. . .)^{3}$

"In the square I see what people see in the face of God", ${ }^{4}$ said Malewicz on many occasions.

The artist also wrote about Suprematism:

"I have undone the knots of wisdom, and I triggered the awareness of color.

Shed the callous skin of the ages as quickly as possible, and it will be easier for you to catch up with us!

I showed the impossible, and created the abyss with my breath." ${ }^{5}$

Over the last century, many research papers, conferences, publications and lectures have been devoted to this work of art. The philosophy of suprematism has become a source of inspiration for many generations of contemporary artists. Renowned international museums around the world are lining up to display the artist's accomplishments, including his most inspiring and mystical painting the Icon of the 20th century - the Black Square on White.

Władysław Strzemiński very accurately described the meaning of Kazimierz Malewicz's work in the context of the centuries to come.

"The basis for the existence of new art () are the paintings by Malewicz an artist of immeasurable greatness - a giant who had a decisive impact on the destiny of art for centuries. Fialkowski

Kazimierz Malewicz The Non-Objective World, the Bauhaus library, translated by Stanislaw

Ibid.

$5 \quad$ Kazimierz Malewicz. Suprematism 
Where Picasso stopped at the very beginning and turned backwards, Malewicz kept going and arrived at... the Suprematism as a system of assembling abstract elements into an organic whole composed according to the objective law." ${ }^{6}$ Władysław Strzemiński (1922)

International exhibitions successively celebrate the work of Kazimierz Malewicz. According to many visitors, the paintings convey a feeling of some vibrant mystical energy. This issue was described by the artist in his poems. According to him,

"with a brush one cannot accomplish what can be accomplished with a pen. While a ruffled brush cannot reach the cerebral ganglia, a pen is sharp enough". ${ }^{7}$

Malewicz not only revolutionized the 20th century art, thereby establishing a new canon; he also wrote experimental/avant-garde poetry.

Malewicz's poetry is a little-known part of his work, and yet it is crucial for understanding the entirety of the artistic legacy of the creator of Suprematism.

His poetry was very diverse in subjects, ranging from a poem describing the summer idyll in the Romanov's estate (1906)6, to poems about nature - which was the cradle and inspiration of his work.

Malewicz's poetic texts changed forms many times, switching from poetry to prose, such as "I am the beginning of everything" (1913), in which Malewicz had a conversation with God. They were written in an abstruse language, which was yet another form of his protest against all conventions, against the popular poetry clichés of the 20th century. The subjects of cubism and suprematism, historical events, or reflections on the artist's further destiny were reflected in his poetry.

An issue that has so far been completely overlooked by researchers of Malewicz's work is the introduction of new words to the Russian language. While some of those words came into use, others were omitted for unknown reasons.

Here are some examples:

Weightlessness is a word of international significance.

Color-writing stands for non-applied production of art forms in a plane without the use of ready-made images created by nature.

\footnotetext{
${ }^{6}$ Professor Janusz Zagrodzki, an article about Kazimierz Malewicz

Ryszard Różanowski, "The new realism in the painting of Kazimierz Malewicz", a quote from Malewicz, page 101
} 


\section{Uncoupledness is a word introduced by Malewicz as the opposite of coupledness.}

Palettists are myopic artists.

Planits are volumetric and spatial arrangements of ultimate geometric forms. $^{8}$

It was Malewicz's planits and architectons that inspired future generations of outstanding architects around the globe.

The influence of Malewicz on architecture and art - even in the 21st century - is boundless.

These visual artists, who took the creative philosophy of Kazimierz Malewicz close to heart and keep reproducing it in the new forms of the 21st century, are exemplified by doctor Sergey Dozhd, an honorary member of the Russian Academy of Arts.

He describes his style and philosophy as SCIARSISM. Created in response to hardening of modern abstractionism, it combines three basic elements: feelings, logic, and intuition.

His works, just as the works of international visual artists calling themselves Sciarsists, attempt to show the inner world of the human in all its dimensions.

In their works, the artists of Sciarsism also reflect the abstraction of all levels of the subconscious.

In order to understand the emotional mystical universe of artists and the journeys of the soul and feelings shown in their paintings-through various stages of the subconscious, up to the Absolute - the viewer must delve into their creative work so intensely as to meet it in the plane of the painting and re-enter the darkness of the Universe to create something new.

The experimental journey through the abysses of the expanded subconscious, delving into, discovering, and recognizing human nature - the psychology of seeing - is worth the effort. Through concentration of that innovative phenomenon we arrive at the philosophy of Sciarsism!

\footnotetext{
8 Words coined by Malewicz, Arzamas.academy
} 